\title{
Freedom of Religious Expression in Malaysia
}

\author{
Mohd Azizuddin Mohd Sani \& Dian Diana Abdul Hamed Shah
}

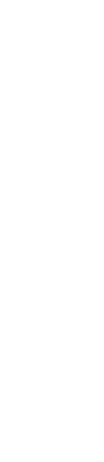

-

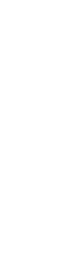

Bible in the Malay language and the controversy over the so called attempt by an opposition party to make Christianity the official religion of Malaysia. The paper explains how these issues have been tackled by the government and society.

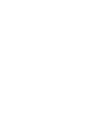

Keywords: Malaysia, Religious Expression, Islam, Christianity, Freedom of Speech.

\section{Introduction}

In Malaysia, the government willingly suppresses religious expression in order to sustain national stability and racial harmony and at the same time, to ensure Sunni Islam remains the dominant faith of the Malays. This is partly to ensure that one of the main political organizations of the Malays the United Malays National Organisation (UMNO) and its partners in the Barisan National coalition continue to remain in power. At the same time, the question of whether Malaysia is a secular or an Islamic state has often cropped up and debated, especially during elections. Although the constitution of the country states that Malaysia is a secular state, in practice however, it has never been totally secular. Malaysia's first Prime Minister, Tunku Abdul Rahman Putra Alhaj had expressed that Malaya/Malaysia is a secular state. But during the Mahathir's tenure as Prime Minister he unilaterally, probably with the intention of challenging Islamic Party (PAS) concept of Islamic state, announced that Malaysia was already an Islamic state. This brought uneasiness among the non-Malay communities who rejected such a notion for Malaysia. Mahathir's successor, 
Abdullah Ahmad Badawi, while concurring with Mahathir's view, however pointed out that Malaysia was neither theocratic nor secular in the real sense of the word. He went on to add that Malaysia will be ruled by following Islamic principles and Parliamentary democratic principles as stated in the Federal Constitution (Lee, 2008: 48).

\section{Freedom of Religion and the Position of Islam}

It is essential also to note that the concept of freedom of religion in Malaysia is rather different from what is practised in the West. It is important to first understand article 3(1) of the Constitution, and appreciate its origin as envisioned by Malaysia's forefathers. It states that Islam shall be the religion of the Federation, but other religions may be practised in peace and harmony in the Federation. In this respect, due regard was given to the elements and traditions of the Malay states long before the colonial period began i.e. the Sultanate, Islamic religion, Malay language, and Malay privilege (Thomas, 2006: 31). Historical evidence suggests that the memorandum discussed the idea of Islam as the religion for Malaysia, but emphasized that this should not affect non-Muslim nationals to profess and practise their religion, and there is no implication that the State is not a secular State (Thomas, 2006: 18-19). ${ }^{1}$ Mr Justice Abdul Hamid, the Reid Commission member from Pakistan opined that the provision on Islam as the religion of the State is innocuous. But the use of the word 'secular' by the founding fathers was never intended to suggest an antireligious or anti-Islamic state of governance (Sarwar, 2007). The Constitution envisages Syariah laws would be enacted to fulfill the personal law requirements of Muslims, but manifestly recognizes that the Syariah would not be made the supreme law. ${ }^{2}$

In the landmark case of Che Omar bin Che Soh v. Public Prosecutor, ${ }^{3}$ the Supreme Court ( 1 was called upon to determine the meaning of article 3 . In the said case, it was emphasized that the British intervention in Malaya separated Islam into the public aspect and the private - aspect; Islamic law was rendered isolated in a narrow confinement of the law of marriage, divorce, and in heritance only (Thomas, 2006: 28). It is only in this sense of dichotomy - that the framers of the constitution understood the meaning of the word Islam in article 3. Scholars like Ahmad Ibrahim also observed that the intention in making Islam the official religion of the Federation was primarily for ceremonial purposes (Thomas, 2006: 29), while Shad Faruqi, a Professor of Law, in his article to The Sun had stressed that '[t]he implication of Islam as religion of the Federation is that Islamic education and way of life can be promoted for Muslims. Islamic institutions can be established. Islamic courts can be set-up, Muslims can be subjected to Syariah laws in certain areas provided by the Constitution' (Faruqi, 2006: 1).

The Constitution also devotes an entire section to detailing fundamental liberties guaranteed for the citizens. Freedom of speech is formally assured in Part II of the Federal Constitution under Article 10(1) entitled 'Freedom of Speech, Assembly and Association'. Article 10(1) allows (a) every citizen has the right to freedom of speech and expression; (b) all citizens have the right to assemble peacefully and without arms; and (c) all citizens have the right to form associations. However, although citizens have a right to freedom of speech, Section 2 of the Article limits the right where Parliament may by law impose: 


\begin{abstract}
'(a) On the rights conferred by paragraph (a) of Clause (1), such restrictions as it deems necessary or expedient in the interest of the security of the Federation or any part thereof, friendly relations with other countries, public order or morality and restrictions designed to protect the privileges of Parliament or of any Legislative Assembly or to provide against contempt of court, defamation, or incitement to any offence;'
\end{abstract}

Article 11 provides for the freedom of religion. ${ }^{4}$ In its literal wording, it seems comprehensive enough to guarantee religious freedom for the plural Malaysian society. A citizen reserves the right to profess, practice and - subject to article 11(4) - to propagate his religion. It is also suggested that this freedom can be construed to mean that one is free to relinquish or change his or her religious belief (albeit with limitations for Muslims under specific religious laws), and even to be not religious (Thomas, 2006: 34). Article 11 is further supported by other Constitutional provisions. For instance, article 149 provides that Parliament may enact laws which would be inconsistent with the fundamental liberties under articles 5, 9, 10 or 13 only if action has been taken or threatened by a substantial body of persons against the nation. Thus, laws which would impinge on article 11 are unconstitutional. Even if a state of emergency is declared, any emergency laws enacted thereafter cannot curtail freedom of religion. ${ }^{5}$ Article 8 also prohibits discrimination on the grounds of religion against public sector employees; in the acquisition or holding of property; and any trade, business or profession.

- Be that as it may, the freedom of religion is subject to several important restraints. A clear example would be article 11(5) which gives deference to public order, public health or morality. The effect is that any religious act which is contrary to general laws relating to these grounds cannot be sustained under article 11. Another controversial limitation is subsection 4's restriction on the propagation of religion among Muslims. It is argued that laws controlling propagation are meant to prevent Muslims from being exposed to heretical religious doctrines, be they be of Islamic or non-Islamic origin, and irrespective of whether the propagators are Muslims or otherwise (Masum, 2009: 3). Shad Faruqi (2001) adds that restrictions are meant to protect Muslims against well-organized and well-funded international missionary activities, and are more concerned with preserving public order and social harmony than with religious priority. The restraints on religious freedom are also developed through case laws, especially on the scope of the word 'practise' in article 11, culminating in the 'non-mandatory practices' doctrine. In essence, this means that freedom of religion extends only to those practices and rituals that are essential and mandatory (Masum, 2009: 4). In Hjh Halimatussaadiah bte Hj Kamaruddin v. Public Services Commission, Malaysia \&Anor, ${ }^{6}$ the court rejected a woman's contention to be allowed to wear a purdah (a headdress covering a woman's entire face except the eyes) to work because the government was entitled to forbid a religious tradition that was non-essential and optional in the interests of the public service. Similarly, in Meor Atiqulrahman bin Ishak \& Ors v Fatimah Sihi \& Ors ${ }^{7}$ the court rejected demands by Muslim boys to be allowed to wear turbans to school. 
In its relationship with article 3 , it should be noted that the freedom of religion is in no way affected, because article 3(4) states that nothing in article 3 derogates from any other provision in the Constitution. However, as stated by article 3(1), the exercise of religious freedom must be done in peace and harmony. It follows that any practice that would contradict 'peace and harmony' cannot be supported by this provision. In the case of Muslim citizens, there may be additional restraints to religious freedom by virtue of Schedule 9, List II, Item I of the Constitution. This grants power to State Assemblies to enact laws to punish Muslims for offences against the precepts of Islam, such as khalwat, adultery, apostasy, gambling, drinking and deviationist activities (Masum, 2009: 3). Despite the foregoing arguments, it should be noted that the establishment of a particular religion over the State is not something that is unique in Malaysia alone. Such practices are common in some western countries as well. For instance in Norway, primacy on Christianity means that the king and a majority of the cabinet are required to be members of the state church (Shelton \& Kiss, 2007: 575), and in England, the Anglican Church remains at the centre of public policy and has substantial support from the state.

In Malaysia, as mentioned in article 11(4), the right to propagate any religious doctrine or belief among persons professing the religion of Islam may be controlled or restricted by State law and Federal law in respect of Federal Territories, Kuala Lumpur and Labuan. Commenting on this restriction, Mohamed Salleh Abas, a former Lord President of Malaysia, said:

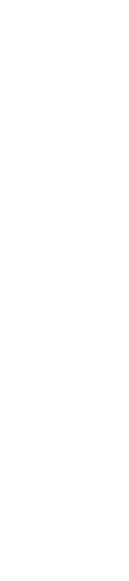

\begin{abstract}
'This limitation is logical as it is necessary consequence that follows naturally from the fact that Islam is the religion of the Federation. Muslims in this country belong to the Sunni Sect which recognizes only the teachings of four specified schools of thought and regards others school of thought as being contrary to true Islamic religion. It is with a view to confining the practice of Islamic religion in this country within the Sunni Sect that State Legislative Assemblies and Parliament as respects the Federal Territory are empowered to pass laws to protect Muslims from being exposed to heretical religious doctrines, be they of Islamic or non-Islamic origin and irrespective of whether the propagator are Muslim or non-Muslim'. (Abas 1984: 10)
\end{abstract}

This limitation would affect both Muslims and non-Muslims. State law may prohibit any attempt by not only non-Muslims to convert Muslims to other religion but also restrict deviation of Muslims from the Sunni Sect to other sects. For non-Muslims, if their religion requires propagation as practice, his right to practice this among Muslims would be severely limited. As longas there are no state laws restricting the right to propagate any religion among Muslim, theoretically this right would be unlimited and any person may exercise the right to propagate any religion among Muslims as well as non-Muslims, unless their acts do not violate Article 11(5). 


\section{Political Stability}

It is obvious that Malaysia is undergoing rapid political and cultural changes. However, the Barisan Nasional government(formerly known as Perikatan) which has ruled Malaysia since Independence in 1957, would want to remain in power. No doubt, political stability has always been on the agenda of $\mathrm{BN}$ manifesto in every general election and $\mathrm{BN}$ is always portrayed as the only protector of the multiracial society. Hasny Md Salleh (2004), a former Colonel in Malaysian Army, argues that Malaysia exercises 'controlled democracy' which simply means that as much as Malaysia is a democratic nation, the government rigidly stipulates what can be done and said. The media community is not spared in this restriction. The government views the media as a 'double-edged weapon' and thus, must be controlled and exploited to the advantage of the government of the day. The government provides the guidelines to the media community on what can and cannot be reported. In this respect the mainstream media is used by the government as its informational tool to reach out to the population, reporting successes of the $\mathrm{BN}$ government and the failures of the opposition party. Hasny points out that all these can be seen as the downside of the Malaysian government. However, he argues that, political instability means losing of foreign direct investment that could give rise to internal security problems such as racial clashes or religious confrontations. Therefore, in Malaysia one must understand that the fragility and diversity of the religious and social structures are potentialities for instability. Efforts are maintained to ensure that a strong government and racial integration remain intact to facilitate and accommodate further development of the nation. However, these are sensitive issues which if not handled accordingly, could give rise to extremism and even terrorism. Malaysia also realizes that it needs to have a strong system of government. Most terrorist organizations operate in countries that have weak and unstable government or what is called failed states. These states become easy targets, for terrorists to promote terrorism. However terrorists will getlittle if not no support in countries that have strong and stable governments. Therefore in Malaysia the government remains sensitive over issues such as race, culture, religion and ethnicity to ensure such issues are not exploited by extremists. The government also ensures that the general social system is viewed as stable with equal distribution of power and rights, both politically and socially. According to Hasny (2004), if all the issues such as the fragile social structure (social integration), extremist religious groups, national security and the role of the media are not handled diplomatically, there will be dire prospects for political instability. Therefore, Hasny advocates that Malaysia needs all its legislative tools such as the restrictive laws of the Internal Security Act (ISA) that allows detention without trial, Official Secret Act (OSA), Sedition Act (SA), and Printing Presses and Publications Act (PPPA) to remain politically and economically stable. This is in line with the statement made by former Prime Minister of Malaysia Mahathir Mohamad to the Far Eastern Economic Review on 28 October 1996 that 'The threat is from inside.... so we have to be armed, so to speak not with guns, but with the necessary laws to make sure the country remains stable' (Mendes, 1994: 2). In the next sections, this paper will discuss those consistencies in relation to the issue of religious expression. 


\section{Religious Expression in the Media}

There have been several incidents of comments and reports in the media deemed sensitive and banned by the government. The talk show Sensasi, which was aired by private station 'TV3', was banned by the Malaysian Communications and Multimedia Commission (MCMC) for an 'inappropriate comment' made against one of the wives of Prophet Muhammad. In another case, the Centre for Independent Journalism (CIJ) reported that the Ministry of Internal Security had banned numerous books in 2007, among others being the translation of Charles Darwin's Origin of Species. Reason given for banning was for advocating an alternative religious view (North, 2007). On 12 June 2007, it was revealed in a dialogue between civil society groups and the Internal Security Ministry that most of the assessments of books on religion and decision to ban them were made by the Department of Islamic Development, Malaysia (Jabatan Kemajuan Islam Malaysia, JAKIM), a department separate from the ministry(Suaram, 2010: 77).

In Malaysia, pictures of pigs are prohibited in the media and pornographic expressions are banned because they are considered unIslamic. There is a strong consensus amongst Malaysians to reject materials of pornographic or sexual nature as immoral and obsceneas they are against all religions and society's value system. Pornography is also seen as a kind of exploitation as it degrades, endangers, and harms the lives of women. Although many in the business argue that the women's involvement in pornography is voluntary, many Malaysians believe that there is an element of exploitation by the pornographic industry.

\section{Controversy Over the Use of the Word 'Allah' by Christians}

เ

One issue that has raised concerns over the exercise of religious freedom in multiracial Malaysia is the controversy over the use of the word 'Allah' by Catholics. In January 2008, - the Malaysian cabinet banned the Catholic newspaper, The Herald, for using the word - Allah' in their publications. The Malaysian government justified the restrictions on the basis that the word 'Allah' refers to God according to the Muslim faith, and as suchits use by non-Muslims may arouse sensitivity and create confusion among Muslims in the country (The Sun, 2008: 1).

1

The Herald filed a case against the government action and in a controversial court ruling on 31 December 2009, Judge Lau Bee Lan allowed The Herald, to use 'Allah' for God in the Malay section of its multilingual newspaper. It was strongly contended that the government's censure against The Herald violates the freedom of religion under article 11, freedom of speech and expression under article 10, as well as article 8's guarantee of equality. The High Court opined that theuse of the word 'Allah' is an essential part of the worship and instruction in the faith of the Bahasa Malaysia-speaking community of the Catholic Church in Malaysia, and therefore is integral to the practice and propagation of their faith.The Home Ministry filed an appeal against this decision on 4 January 2010, which to date, there has been no indication as to when the case will be heard (Kay, 2011). Proponents of the Government suggest that 'Allah' is exclusive for Muslims, and giving Catholics the right to use 'Allah' disregards article 3 because such use will somehow erode the position 
of Islam in the country and cause confusion among Muslims. It is difficult however, to see the wisdom of this argument especially since article 3 does not affect the exercise of other rights espoused in the Constitution. Furthermore, in other Muslim countries, even in the Middle East, where the Muslim and Christian communities together use the word 'Allah', one hardly hears of any confusion arising. ${ }^{8}$ For those who support The Herald's position, they claim a violation of article 11's right to religious freedom. To these people, the use of the word 'Allah' is central in the practice of their religion. But the widespread concern among the Muslims is that such use would strike the prohibition against propagation of other religions to Muslims. It is believed that the Catholic Church would use it as a tool to proselytize members of the Muslim majority, as against article 11(4) of the Constitution. However, a non-Muslim would only commit an offence if he uses the word 'Allah' to a - Muslim but there would be no offence if it was used to a non-Muslim.

The other side of the argument suggests that this controversy be looked at through the 'nonmandatory practices' lens. This restraint has been invoked by courts to allow only religious practices that are deemed 'essential and mandatory.' One could make out an argument that other than using the word 'Allah', the Catholics could instead use the Bahasa Malaysia equivalent of 'God' - which is Tuhan - in their publications. Hence, the use of 'Allah' is neither mandatory nor essential to practice the religion. But it is this very line of reasoning that has drawn concerns from those who believe that it may create problems in areas where some practices, though not mandatory, is however part and parcel of certain religions (Masum, 2009: 4). Another potential danger of invoking the 'essential and mandatory' reasoning lies in the fact that religious practices often vary not only from one place to another, but also from one community to another. So who is to decide what is 'essential and mandatory'? If this reasoning is used to sustain a uniform, blanket rule on 'necessary' practices, then we have no business in claiming cultural (or religious) relativism because to impose what is necessary or not contradicts the very heart of the relativist argument. As such, it is clear that arguments from both sides of the divide have some flaws which need to be addressed urgently. The debate on this issue remains unresolved.

In the international human rights regime, the freedom to 'manifest one's religion or belief in teaching, practice, worship and observance either in public or in private' is clearly recognised. Broadly speaking, we can conclude that this includes the use of a particular word or reference in publications distributed to adherents of a particular faith. The Human Rights Commission's General Comments to article 18 of the International Covenant on Civil and Political Rights (ICCPR) sheds some light in understanding what is contemplated by the human rights regime. It is recognized that the freedom to manifest religion or belief in worship, observance, practice and teaching encompasses a broad range of acts, including ritual and ceremonial acts, as well as customs like the observance of dietary regulations, the wearing of distinctive clothing or head coverings, participation in rituals associated with certain stages of life, and the use of a particular language customarily spoken by a group. ${ }^{9}$ In addition, the practice and teaching of religion or belief includes acts integral to the conduct by religious groups of their basic affairs, one of which is the freedom to prepare and distribute religious texts or publications. Given these, the position taken by the Malaysian government is inconsistent with international conceptions of human rights. It is 
also worth mentioning that international scholars such as Tariq Ramadan seemingly share the sentiments against the prohibition to use 'Allah' in Malaysia. Ramadan suggests that for centuries Christian Arabs have been using 'Allah' in Arabic to refer to God, and likewise Muslims have used different words when speaking of God in different languages (Koya, 2010). Thus this case is unique in Malaysia in the sense the Malays claim ownership and exclusivity on the use of the word 'Allah' which they believe should not be used by the other faiths in reference to their gods. This is definitely a sensitive religious, political and cultural issue which can have far-reaching consequences on race-relations in the multiracial society of Malaysia.

\section{Bible in Bahasa Malaysia Issue}

Closely related to the 'Allah' issue, is the Bible in the Malay language or Bahasa Malaysia issue. The Malaysian government detained 35,100 copies of the Bible and imposed certain conditions for their release. The Home Ministry stamped the words, 'This Good News [Malay] Bible is for use by Christians only'. Besides that the covers of these Bibleshad to carry serial numbers, on 5,100 copies. This was done without consulting the importer, the Bible Society of Malaysia (BSM), which initially refused to collect them as it had neither accepted nor agreed to the new conditions. The Home Ministry stamped the serial numbers a day after the government had, on 15 March 2011, issued a release order for the Bibles which had been detained in Port Klang. Another 30,000 copies were detained at a port in Kuching after the Sarawak state Home Ministry told the local chapter of Gideons International that it could collect them if the organization would put the stamp on them. Gideons has thus far declined to do so, and a spokesman said on 5 April 2011 officials had already defaced the books with the stamp. Home Minister Hishammuddin Hussein has said the act of stamping Cand serialization was standard protocol (Kay, 2011).In the weeks following the 15 March 2011 release order, the government made several attempts to try to appease the Christian - community through Idris Jala, a Christian from Sarawak state and a minister in the Prime - Minister's Department. Idris issued the government's first statement on 22 March 2011, - explaining that officials had reduced earlier conditions imposed by the Home Ministry to require only the words, 'For Christianity' to be stamped on the covers of the Bible in font type Arial, size 16, in bold. On 2 April 2011, Idris issued a 10-point statement to try and resolve the impasse. ${ }^{10}$ Significantly among others, this latest overture by the government included the lifting of present restrictions to allow for local printing and importation of Malay and other indigenous-language Bibles into the country (Kay, 2011).

Most Christians responded to this latest overture with caution. Many remained skeptical, seeing it as a politically motivated move in view of Sarawak state elections on 16 April 2011. Nearly half of Sarawak's population is Christian. However, the 10-point proposal has also drawn the ire of Muslim groups, who view it as the government caving in to Christian pressure. Perak Mufti Harussani Zakaria and the Muslim Organizations in Defense of Islam (Pembela) expressed their disappointment and tried to challenge the 10-point proposal in court if it was not reviewed in consultation with Muslim representatives especially the issue of Malay Bibles.So we find that the issue of the Bible in the Malay language and the use of the word 'Allah' by non-Muslimsare closely tied to one another in the dispute. 


\section{Controversy Over 'Christianity the Official Religion of Malaysia'}

Another controversial issue which attracted the attention of the authorities and the public was the issue of establishing Christianity as Malaysia's official religion. The Malay daily, Utusan Malaysia, carried a front-page article on 7 May 2011, headlined 'Kristian agama rasmi?' (Christianity the official religion?), claiming the opposition Democratic Action Party (DAP) was conspiring with Christian leaders to take over Putrajaya and abolish Islam as the religion of the federation. The report, based entirely on unsubstantiated blog postings, 'Bigdog' and 'Marahku', by several pro-UMNO bloggers, charged the DAP with sedition for allegedly trying to change the country's laws to project for a future Christian prime minister. In response to the allegation, Datuk Ibrahim Ali president of PERKASA, a right wing group called for a 'crusade' against Christians who challenge Islam's position. This issue was disturbing for race relations in Malaysia. Christian groups and the DAP have repeatedly denied the allegation, and have slammed the UMNO daily for printing 'dangerous lies' (Chong, 2011).

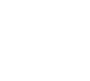

口.

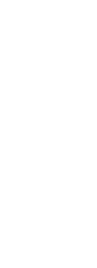

10

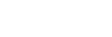

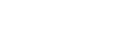

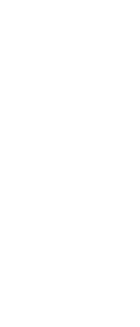

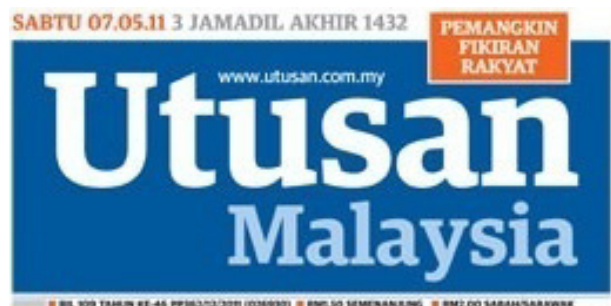
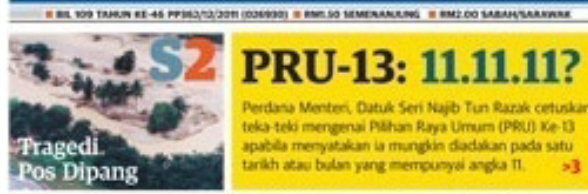

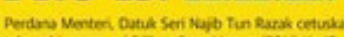
teks tedo mengensi Pathon Ravi Umum (Phu) Ke - 1 )

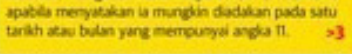

- Dua laman blog dedah ikrar paderi seluruh negara - Jeff Ooi nafi anjur majlis Kristian agama rasmi?

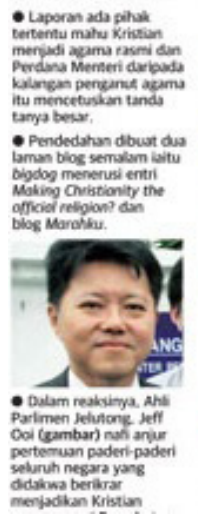

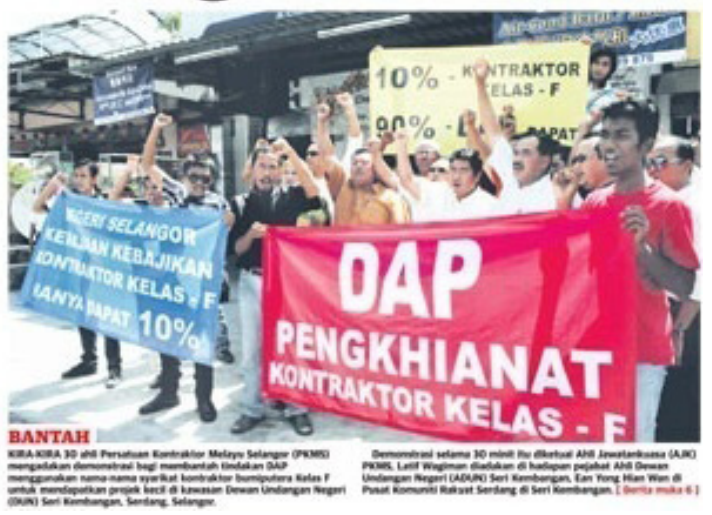

Source: (Utusan Malaysia 2011: 1).

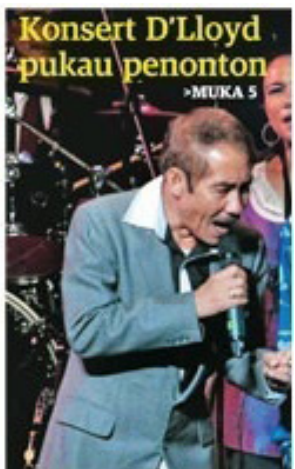


Lim Guan Eng, the Secretary General of DAP who is also the Chief Minister of Penang, denied these claims that his party was behind the move. He lodged a complaint against the newspaper with the police. He explained that 'We have never asked for Malaysia to become a Christian, Hindu or Buddhist state'. The dinner was organized by the National Evangelical Christian Fellowship, Global Day of Prayer, Marketplace Penang and the Penang Pastors Fellowship. The organizers had insisted that the only issues discussed at the dinner were related to corruption and bribery in the marketplace and had nothing to do with Christianity's position in Malaysia (Matheson, 2011). ${ }^{11}$

Later, Hishammuddin Tun Hussein, the Home Minister, issued a warning letter to Utusan Malaysia newspaper on 12 May 2011 over of a report considered alarming to the public. However, according to the Associate Press (AP), neither the newspaper nor its editors were reprimanded, and no apology was issued to Christians (The Underground, 2011). Members of the opposition and some ruling party officials said the reprimand fell short, and called for suspension of Utusan Malaysia and its editor for inflammatory reporting that added fuel to Dexisting religious tensions. The Malaysian Chinese Association (MCA), which is the second largest party in the ruling coalition, also expressed displeasure that only a mere warning was issued against Utusan Malaysia, and said the editor should have been suspended and the two bloggers punished. Chua Soi Lek, President of the MCA told the AP, 'We hope that the government will not compromise and should uphold justice and send a clear message to Malaysians that religion should not be used in the political battle' (The Underground, 2011). Meanwhile, Teresa Kok, an opposition lawmaker, called for the revocation of Utusan Malaysia's license, saying this would illustrate the government's commitment to quell attempts at religious and ethnic provocation(Su-Lyn, 2011).

(

- The Persatuan Promosi Hak Asasi Manusia (Proham) and its Deputy Chairman Hamdan

- Adnan (2011) expressed great concern over the unprofessional way in which a local daily had acted in betraying the basic principles of responsible journalism. The Utusan Malaysia - headline was based on an unverified blog article, without any reference to the concerned parties mentioned. The matter at hand was highly sensitive and the daily could be found guilty of orchestrating racial and religious conflict. Due to the insensitive nature of its news coverage on Saturday and Sunday, Utusan Malaysia could also be guilty of misleading its Malay and Muslim readers. Furthermore, Utusan Malaysia can be construed to be undermining national unity and the 1 Malaysia agenda of Prime Minister, Najib Razak. So while Proham affirmed the freedom of the media as a human right but at the same time it called on all parties, both the traditional and new media not to fabricate or manipulate news, but to act in a responsible way especially in reporting matters pertaining to racial and religious issues. In a recent Centre for Independent Journalism and Bar Council forum titled 'Towards a more ethical media', political scientist Wong Chin Huat said the freedom to offend is part of the price for freedom of speech. He said, 'What is not acceptable, however, is physical violence or threats of violence... The state has failed to come down on threats of violence. If you remove impunity for violence and threats of violence, then we don't have to be afraid' (Choo, 2011: 1). 
Prime Minister Najib Razak when he met some Christian leaders in Malaysia on 12 May 2011 was reported to have said that the group had pledged to respect the position of Islam as Malaysia's official religion and that they have no intention of challenging the provision enshrined in the Federal Constitution. The Prime Minister said the group had also given their undertaking to cooperate in nurturing peace and harmony between the various faiths so that Malaysia would continue to be a peaceful and prosperous nation (The Borneo Post Online, 2011). However, this incident shows that how irresponsible reporting can stir instability in the country no matter for what ever reasons the report was intended. It has the tendency to tarnish the image of Malaysia and question the tolerance in race relations in the country. This has failed the 1Malaysia concept in establishing harmony and prosperity especially in race relations. Therefore, the government parties, the opposition, civil societies and the public should all ensure that irresponsible religious expression should be avoided and issues, especially those related to religion should be tackled wisely and carefully for the common good of the Malaysian society.

\section{Conclusion}

In Malaysia, religious expression is allowed only if it is approved by the state and religious authority as long as it follows the teaching of Sunni sect. This is definitely protected by the constitution as Islam is the religion of the federation, but other religions are allowed to be practiced by their followers. Besides, Malaysia is now declared by the government as the Islamic state even though there is no clear consensus reached in this matter especially from the non-Muslims.Furthermore, many things secular and non-religious are considered

- Islamic. Learning about non-Islamic philosophy such as Marxism and liberalism is accepted and considered Islamic in the sense that it would strengthen the Islamic beliefs among the Muslims. There are also many restrictions imposed on religious expression which include book publication, dress codes, the media reporting, and blasphemy. What is obvious is that religious freedom and religious expression are very sensitive issues in Malaysia. The government is trying to protect political stability and racial harmony in Malaysia, but at the same time it tries to maintain the present status-quo as a regime security mechanism. While the issue can be so complicated but issues in a plural society such as Malaysia must also be opened to civilized, intellectual debates by all sections of the community. While concerns over social stability is understandable, any action by the government must be seen to be just and reasonable and not infringing basic human rights and dignity. 


\section{End Notes}

1 The White Paper issued by the British Government on 14 June 1957, which contained the constitutional provisions for an independent Malaya, reiterated that a declaration of Islam as the religion of the Federation will in no way affect the present position of the Federation as a secular State.

Sarwar also argues that 'Unlike the Constitution of Pakistan that entrenches the Syariah as the basis of all law, the Federal Constitution does not accord the syariah law such status.'

Che Omar bin CheSoh v. Public Prosecutor [1988] 2 MLJ 55. In that case, the accused was faced with a mandatory death sentence for drug trafficking. He challenged the sentence on the basis that the imposition of death penalty for the offence is contrary to Islamic injunction and therefore, unconstitutional and void.

Article 11 reads:

(1) Every person has the right to profess and practice his religion and, subject to Clause (4), to propagate it.

(2) No person shall be compelled to pay any tax the proceeds of which are specially allocated in whole or in part for the purposes of religion other than his own.

(3) Every religious group has the right -

(a) to manage its own religious affairs;

(b) to establish and maintain institutions for religious or charitable purposes; and

(c) to acquire and own property and hold and administer it in accordance with law.

(4) State law and in respect of the Federal Territories of Kuala Lumpur, Labuan and Putrajaya, federal law may control or restrict the propagation of any religious doctrine or belief among persons professing the religion of Islam.

(5) This article does not authorize any act contrary to any general law relating to public order, public health or morality.

Article 150 (6A) of the Constitution.

[1994] 3 MLJ 61.

[2006] 4 CLJ 1.

8 Titular Roman Catholic Archbishop of Kuala Lumpur v. Menteri Dalam Negeri\&Anor.[2010] 2 CLJ 208, 214; High Court Malaya, Kuala Lumpur, Judicial Review No. R1-25-28-2009, 31 December 2009.

9 Human Rights Committee, General Comment No. 22: The right to freedom of thought, conscience and religion (Art. 18), at para. 4. http://www.unhchr.ch/tbs/doc.nsf/(Symbol)/ 9a30112c27d1167cc12563ed004d8f15? Opendocument. 
10 The solution is as follows:

(1) Bibles in all languages can be imported into the country, including Bahasa Malaysia/Indonesia.

(2) These Bibles can also be printed locally in Peninsula Malaysia, Sabah and Sarawak. This is a new development which should be welcome by the Christian groups.

(3) Bibles in indigenous languages of Sabah and Sarawak such as Iban, Kadazan-Dusun and LunBawang can also be printed locally and imported.

(4) For Sabah and Sarawak, in recognition of the large Christian community in these states, there are no conditions attached to the importation and local printing of the Bibles in all languages, including Bahasa Malaysia/Indonesia and indigenous languages. There is no requirement for any stamp or serial number.

(5) Taking into account the interest of the larger Muslim community, for Peninsular Malaysia, Bibles in Bahasa Malaysia/Indonesia, imported or printed, must have the words 'Christian Publication' and the cross sign printed on the front covers.

(6) In the spirit of 1Malaysia and recognising that many people travel between Sabah and Sarawak and Peninsular Malaysia, there should be no prohibitions and restrictions for people who bring along their bibles and Christian materials on such travel.

(7) A directive on the Bible has been issued by the Secretary General (KSU) of the Home Ministry to ensure proper implementation of this cabinet decision. Failure to comply will subject the officers to disciplinary action under the General Orders. A comprehensive briefing by top officials, including the Attorney General (AG), will be given to all relevant civil servants to ensure good understanding and proper implementation of the directive.

(8) For the impounded Bibles in Kuching, Gideon, the importer can collect all the 30,000 Bibles free of charge. We undertake to ensure the parties involved are reimbursed. The same offer remains available for the importer of the 5,100 Bibles in Port Klang, which have already been collected by the Bible Society Malaysia (BSM).

(9) Beyond the Bible issue, the Government wishes to reiterate its commitment to work with the Christian groups and all the different religious groups in order to address inter religious issues and work towards the fulfilment of all religious aspirations in accordance with the constitution, taking into account the other relevant laws of the country. In order to bring urgency to this work, the Prime Minister will meet the representatives of the Christian Federation of Malaysia (CFM) soon to discuss the way forward.

(10) The Christian Ministers in the cabinet will meet on a regular basis with representatives of the various Christian groups in order to discuss their issues and work with the relevant Ministries and Prime Minister in order to resolve them.

11 This statement was confirmed by Paul Low, the President of Transparency International Malaysia (TI-M) who attended the conference. He explained that: 'I categorically confirm that no pact or pledge for Christianity as official religion or for a Christian prime minister was made on the evening of May 5 or at any time during the conference' (Alhadjri 2011: 1). 


\section{References}

Abas, M.S. (1984). Selected articles \& speeches on constitution, law \& judiciary. Kuala Lumpur: Malaysian Law Publishers.

Abdullah, N. (2007). Legislating faith in Malaysia. Singapore Journal of Legal Studies, 264-289.

Adil, M.A. M. (2007). Restrictions in freedom of religion in Malaysia: A conceptual analysis with special reference to the law of apostasy. Muslim World Journal of Human Rights, $4(2), 10-11$.

-

Alexander, L. (1993). Liberalism, religion, and the unity of epistemology. San Diego Law Review, 30, 775-776.

Alhadjri, A. (2011, May 19). Issue never rose. The Sun.

Audi, R. (1989). The separation of church and state and the obligations of citizenship. Philosophy and Public Affairs, 18, 259-276.

Audi, R. (1993). The place of religious argument in a free and democratic society. San Diego Law Review, 30, 677-700.

Audi, R. (1997). Liberal democracy and the place of religion in politics. In Robert, A. \& Nicholas, W. (Eds.), Religion in the public square: The place of religious convictions in political debate. Lanham, Md: Rowman and Littlefield.

$=0$

- Audi, R. (2000). Religious values, political action, and civic discourse. Indiana Law —. Journal, 75, 273-280.

Baker, C. E. (2002). Media, markets, and democracy. Cambridge: Cambridge University Press.

British Broadcasting Corporation (BBC). (2006). Islam-west divide 'Grows Deeper'. BBC News. Retrieved from http://news.bbc.co.uk

Chong, D. (2011). PM to meet church leaders amid Christian Malaysia row. The Malaysian Insider. Retrieved from http://www.themalaysianinsider.com

Choo, N. (2011). Fighting the likes of Ibrahim Ali and Utusan Malaysia. The Nutgraph. Retrieved from http://www.thenutgraph.com

Faruqi, S. S. (2001, February). Support for religious liberty. Sunday Star. 
Faruqi, S. S. (2004). Constitutional law, rule of law and systems of governance in Islam. in Islam, democracy and good governance: The Malaysia experience. Ibrahim A.S. (Ed.), Shah Alam: UPENA.

Faruqi, S. S. (2006). Freedom of religion under the constitution. The Sun. Retrieved from: http://www.sun2surf.com

Gatsiounis, I. (2006). In Malaysia, 'too sensitive' for debate. Asia Times. Retrieved from http://www.atimes.com

Greene, A. S. (1993). The political balance of the religion clauses. Yale Law Journal, 102, 1611-1633.

Hamdan Adnan. (2011). A call for responsible journalism. The Malaysian Insider, Retrieved from http://www.themalaysianinsider.com

Hasny Md Salleh. (2004). War against terrorism: Malaysia's experience in defeating terrorism. Carlisle Barracks, Pennsylvania 17013: U.S. Army War College.

Kay, J. (2011). Malaysian christians seek to end restrictions on malay bibles. Compass Direct News. Retrieved from http://www.crosswalk.com

Koya, Z. (2010). On respect, thinking, and dialogue. The Sun. Retrieved from http:// sun2surf.com

Lee B. C. (2008). Bagaimana keris diganti dengan merpati? Kuala Lumpur: Oriengroup.

Loone, S. (2002). Malaysiakini.com. Retrieved from http://www.malaysiakini. com

Magarian, G.P. (2010, February 16). Religious argument, free speech theory, and democratic dynamism. Retrieved from http://www.thedivineconspiracy.org/Z5241W.pdf

Mahathir Mohamad. (1999). A new deal for Asia. Selangor: Pelanduk Publication.

Marshall, W. P. (1993). The other side of religion. Hastings Law Journal, 44, 843-858.

Masum, A. (2009). Freedom of religion under the Malaysian federal constitution. Current Law Journal (CLJ), 2, 1-3.

Matheson, A. (2011). Christians accused of trying to turn Malaysia into christian state. The Christian Post. Retrieved from http://www.christianpost.com

Maznah, M. (2002). Islam and the politics of free speech. Aliran Monthly, 22 (1). 
Danish paper rejected Jesus cartoons. (2006). Media Guardian. Retrieved from http://www. guardian.co.uk

McConnell, M. W. (1999). Five reasons to reject the claim that religious arguments should be excluded from democratic deliberation. Utah Law Review, 1999, 639-648.

McIntyre, I. (2006). MB defends dress code. The Star Online. Retrieved from http://www. thestar.com.my

Mendes, E. P. (1994). Asian values and human rights: Letting the tigers free. Ottawa: Human Rights Research and Education Centre, University of Ottawa. Retrieved from http://www.uottawa.ca

Moses, B. (2002). Ethnic reporting in the Malaysian media. Media Asia, 29, (2) 102-107.

Muslim Scholars Association of Malaysia (MSAM). (2002). Kontroversi mengenai memo kepada Majlis Raja-Raja Melayu. Petaling Jaya: MSAM.

-

Muzaffar, C. (1989). Challenges and choices in Malaysian politics and society. Penang: Aliran Kesedaran Negara (ALIRAN).

Richard J., \& Neuhaus, R. J. (1984). The naked public square: Religion and democracy in America. Grand Rapids Mi: Eerdmans.

North, M. (2007). World press freedom review 2007: Malaysia. Vienna: International Press 10 Institute.

- Office of the United Nations High Commissioner for Human Rights. (1993). General

Office of the United Nations High Commissioner for Human Rights. (1993). General
comment No. 22: The right to freedom of thought, conscience and religion (Art. 18),

CCPR/C/21/Rev.1/Add.4 (30 July 1993) [General Comment No. 22]. Office of the United Nations High Commissioner for Human Rights.

Rawls, J. (1996). Political liberalism. NewYork: Columbia University Press.

Rawls, J. (1997). The idea of public reason revisited. University of Chicago Law Review, $64,765-768$.

Rorty, R. (1994). Religion as conversation stopper. Common Knowledge, 3, (1) 16-6.

Sarwar, M. I. (2007). Latifah Mat Zin: Reaffirming the supremacy of the constitution. Retrieved from http://malikimtiaz.blogspot.com

Shelton, D., \& Kiss, A. (2007). A draft model law on freedom of religion. In Henry J. Steiner et al. (Eds). International Human Rights in Context: Law, Politics, Morals. Oxford: Oxford University Press. 
Suara Rakyat Malaysia (Suaram). (2010). Malaysia human rights report 2009: Civil \& political rights. Petaling Jaya: Suaram Komunikasi.

Sullivan, K. M. (1992). Religion and liberal democracy. University of Chicago Law Review, $59,195-199$.

Su-Lyn, B. (2011). Revoke Utusan's licence, Teresa tells Hisham. The Malaysian Insider, Retrieved from http://www.themalaysianinsider.com

The Borneo Post Online. (2011). Bernama: Christian leaders have no intention to dispute Islam's position - Najib. Retrieved from http://www.theborneopost.com/

(2008, January 4). Cabinet: Allah for muslims only. The Sun.

(2011). Malaysia scolds publication for spreading rumor, no apology to Christians. The Underground. Retrieved from http://theundergroundsite.com/

- Thomas, T. (2006). Is Malaysia an Islamic state? Malayan Law Journal Article (MLJA), $15-17$.

Kristian agama rasmi? .(2011). Utusan Malaysia.

Waldron, J. (1993). Religious contributions in public deliberation. San Diego Law Review, $30,817-829$.

Yeoh S. G. (2005). Managing sensitivities: Religious pluralism, civil society and interfaith relations in Malaysia. The Round Table, 94, (38), 629-640. 


$$
\begin{aligned}
& \text { हे } \\
& \text { כ } \\
& \overline{0} \\
& \text { (1) } \\
& \frac{\varepsilon}{\Xi} \\
& \text { ( ) } \\
& \sqrt{\square \quad} \\
& \text { 음 } \\
& \text { 政 } \\
& \text { ع }
\end{aligned}
$$

